Çanakkale Onsekiz Mart Üniversitesi
Fen Bilimleri Enstitüsü Dergisi
Açık Erişim

\title{
Manisa İli’nde Çiftçilerin Tarım İlaçları Kullanımı Konusundaki Bilinç Düzeyi ve Duyarlılıklarının Araştırılması
}

\author{
Mehmet Erdil $^{1}$, Osman Tiryaki $^{2} *$ \\ ${ }^{1}$ Bitki Koruma Anabilim Dalı, Fen Bilimleri Enstitüsü, Çanakkale Onsekiz Mart Üniversitesi, Çanakkale, Türkiye \\ ${ }^{2}$ Bitki Koruma Bölümü, Ziraat Fakültesi, Çanakkale Onsekiz Mart Üniversitesi, Çanakkale, Türkiye
}

$\begin{array}{ll}\text { Makale Tarihçesi } \\ \text { Gönderim: } & 25.11 .2019 \\ \text { Kabul: } & 27.01 .2020 \\ \text { Yayım: } & 22.05 .2020\end{array}$

Araștırma Makalesi

\begin{abstract}
Öz - Küresel ısınma ve iklim şartlarının bozulmasından kaynaklı kültür bitkilerinde zararlı organizmalarda artış görülmekte, kimyasal kullanımı da artmaktadır. Bu çalışmanın amacı Manisa İlinde çiftçilerin pestisit kullanımındaki bilinç düzeyi ile duyarlılıklarının araştırılmasıdır. Anket yapılacak çifţi sayısı 'Oran Ortalamalarına Dayalı Basit Rastgele Örnekleme' yöntemi ile hesaplanarak, 384 çiftçi ile çalışma yapılmıştır. Ankete katılan çiftçilerin \%31.2'si 21-30 yıl çiftçilik tecrübesi olduğunu, \%53.1 ilkokul mezunu olduğunu, \%30.2'si 45-54 yaş aralığında olduğunu belirtmiştir. Çiftçilerin pestisit kullanımı bilinç seviyeleri Likert Skalası uygulayarak hesaplanmış ve \%63.8'i yüksek, \%25.3'ü orta, \%10.9'u düşük bilinç düzeyinde bulunmuştur. Çiftçilerin bilinç düzeyi ile eğitim seviyesi, yaş, çiftçilik deneyimi ve arazi varlığı arasında ilişkinin varlığı da Khi-Kare $\left(x^{2}\right)$ Bağımsızlık Testi ile araştırılmıştır. Buna göre bilinç düzeyi ile eğitim seviyeleri arasındaki ilişki önemli bulunmuş, bağımsızlık katsayı da 0.344 olarak belirlenmiş̧ir. Eğitim seviyesi arttıkça bilinç düzeyi de artmış ve çiftçilikte tecrübe sahibi ve iyi eğitim almış kişilerin bilinç düzeyleri yüksek çıkmıştır. Bu sonuçla çoğu disiplinde olduğu gibi eğitimin rolünün önemi bir kez daha ortaya çıkmıştır. Çiftçilerin $\% 63.8$ 'i yüksek bilinç düzeyine sahip gözükmekte ise de üreticilerin $\% 60.7$ 'si ilaçlama sonrası kıyafetini değiștirmediğini, \%74.2'si pestisit etiket üzerindeki uyarı ve işaretleri bilmediğini, \%63'ü pestisit kullanımı sırasında koruyucu ekipman kullanmadığını belirtmiştir. Çalışmada özel ve resmi tarımsal kurum ve kuruluşların pestisitlerle ilgili çiftçi bilinçlendirmesindeki önemi ortaya çıkmıştır.
\end{abstract}

Anahtar Kelimeler - Manisa, pestisit, bilinç düzeyi, çevresel tutum, Likert skalası

\section{Investigaton of the Knowledge Level and Awareness of Farmers About Pesticide Usage in Manisa}

${ }^{1}$ Plant Protection Department, Graduate School of Applied Sciences, Çanakkale Onsekiz Mart University, Çanakkale, Turkey

${ }^{2}$ Plant Protection Department, Faculty of Agriculture, Çanakkale Onsekiz Mart University, Çanakkale, Turkey

Article History

Received: $\quad 25.11 .2019$

Accepted: $\quad 27.01 .2020$

Published: $\quad 22.05 .2020$

Research Article

\begin{abstract}
With the global warming and the climatic deterioration, there is an increase in pests and the use of chemicals are increasing. The aim of this work is to investigate the knowledge level and farmers awareness about pesticide usage in Manisa. The number of farmers to be surveyed was calculated by "Simple Random Sampling Based on Ratio Means" method. The survey was carried out with 384 farmers. 31.2\% of the farmers stated that they had 21-30 years of farming experience, $53.1 \%$ were primary school graduates and $30.2 \%$ were $45-54$ years old. The farmers knowledge level on pesticide was calculated by applying Likert Scale. The knowledge level of farmers was high, moderate and low with the percentage of $63.8 \%, 25.3 \%$ and $10.9 \%$, respectively. The Chi-Square $\left(x^{2}\right)$ test was used to investigate the relationship of farmer's knowledge level with education, age, farming experience and land size. The relationship between the knowledge level and education was significant and coefficient contingency was 0.344. As education level increased, the knowledge level increased and the knowledge level of the people who had experience in farming and well educated was high. With this result, the importance of the role of education, as in most disciplines, has once again emerged. $63.8 \%$ of the farmers have a high knowledge level, but $60.7 \%$ of the farmers do not change their clothes after spraying, $74.2 \%$ don't know the special signs and warnings on pesticide labels, 63\% don't use protective equipment during pesticide use. The significance of the effect of private and official agricultural institutions and organizations on farmer awareness about pesticides has emerged.
\end{abstract}

Keywords - Manisa, pesticide, awareness, environmental attitude, Likert scale.

\footnotetext{
1 (D) http://orcid.org/0000-0001-9286-9624 mehmeteerdil@ gmail.com

2 (i) http://orcid.org/0000-0002-7509-8423 osmantiryaki@yahoo.com

*Sorumlu Yazar / Corresponding Author
} 


\section{Giriş}

Manisa tarımsal üretimi ile Türkiye tarımında önemli bir kenttir. Manisa'da zeytin, kuru ve yaş üzüm, tütün, pamuk, kiraz ve tahıllar gibi bitkisel ürünler üretilmektedir. Bu ürünlerden kalite ve kantite olarak yeterli ürün alabilmek için pestisitlerin kullanımı da kaçınılmazdır. Türkiye'de pestisit tüketimi, yoğun tarımın yapıldığı Akdeniz ve Ege Bölgelerinde daha fazladır. Bu bölgelerde tüketim, Türkiye tüketiminin \%34'den fazlasını, bazı yıllarda da \%50'sini oluşturmaktadır. Akdeniz ve Ege Bölgeleri, beslenmede önemli rolü olan meyve ve sebzelerin en fazla yetiştirildiği alanlardır (Delen vd., 2005).

Günümüzde bitkilerde görülen hastalık ve zararlı oranlarında artış görülmekte ve buna paralel olarak Türkiye'de pestisit kullanımları artmaktadır (TÜİK, 2019). Türkiye'de pestisit bilinçsiz olarak ya da ticari kaygılardan kaynaklı yanlış kullanılmaktadır. Zararlı organizmalarla (hastalık, zararlı ve yabancı otlar) mücadelede kısa sürede etkili olan ve sonuç alınan yöntemlerin başında kimyasal mücadele gelmektedir. Zararlı organizmalara karşı mücadele metotları içerisinde kimyasal mücadele uygulaması, \%95'den fazla bir paya sahiptir. Tarımsal üretimde tarım ilaçları kullanılmaz ise bazı yıllarda $\% 60$ oranında kalite ve verim düşüklüğü olmaktadır. Bu nedenle, tarım ilaçlarının kullanılması kaçınılmazdır (Tiryaki vd., 2010). Ancak tarım ilaçlarının hedef dışı organizmalara ulaştığı ve çevre üzerinde de olumsuz etkilerinin bulunduğu göz ardı edilmemelidir. Tarım ilaçlarının sorumsuzca ve kontrolsüz kullanımı, halk sağlığını tehdit sürecini hızlandırmaktadır (Tarakçı vd., 2009). Gelişmiş ülkeler 1980'li senelere kadar üretim artırmak, birim alandan en fazla ürün almak ve girdileri minimize etmek için, tarım politikaları geliştirmişlerdir (Delen vd., 2015; Tiryaki, 2016).

Tarımsal faaliyetlerde bu ilaçların kullanımı, buharlaşarak havaya, yer altı ve yüzeysel sulara ve toprağa karışarak çevre kirliliğine neden olmaktadır. Bu sebeple kirlilikler artmakta ve doğada yaşayan diğer canlılar da olumsuz etkilenmektedir. Pestisitleri, insanlar; solunum sindirim ve temas ederek vücutlarına almaktadırlar. Vücuda giren pestisitler kronik ve akut zehirlenmeler oluşturabilmektedir (Tosun vd., 2001).

Bu olumsuzlukları engellemek için üreticilerde güvenli pestisit kullanımı bilincinin oluşması gerekir (Altıkat vd., 2009). Sürdürülebilir bir çevre için çevredeki doğal kaynakları kullanmada gelecek nesillerin hakk1 gözetilerek bu kaynakların korunup değerlendirilmesi amaçlanmalıdır (WCED, 1987). Dünyayı gelecekte bekleyen risklerden korumak için yapılması gereken sürdürülebilir çevre yaklaşımlarını tüm dünyada geçerli kılmaktır.

Pestisitlerin sebep olduğu çevre kirliliğinin önüne geçmek ve pestisit kalıntılarından ari ürün üretebilmek için toplumun bilinç düzeylerinin artırılması ve tarım ilacı uygulayanların eğitilmesi gerekir. Tarım Bakanlığı yaptığı bir düzenleme ile pestisit uygulayanların eğitim alarak pestisit uygulama belgesi almalarını gerekli kılmıştır (Resmi Gazete, 2014). Tarım ilacı kullanımının kalıntı, dayanıklılık ve çevresel riskleri tarım ilacı tüketimini etkileyen unsurlardır. Çiftçilerin tarım ilacı uygularken ve uygulamadan sonraki davranışları söz konusu riskleri karakterize eden faktörlerdir. $\mathrm{Bu}$ sebeple üreticilerin tarım ilacı seçimindeki ve kullanımındaki eğitim ve bilinç düzeylerinin belirlenmesi çok önemlidir (Delen vd., 2015).

Türkiye'de üreticilerin tarım ilaçları kullanımı konusunda tutumları davranışları ve çevresel duyarlılıkları ile ilgili birçok çalışma vardır. Peker, (2012), Konya ilinde domates yetiştiriciliğinde tarımsal savaşta pestisit kullanan çiftçilerin çevre bilinçlerinin belirlenmesi hedeflenmiştir. Bu araştırma domates yetiştiriciliğinin yoğun olarak gerçekleştirildiği Çumra ilçesinde yapılmıştır. Çalışmada kullanılan bilgiler 50 domates çiftçisinden anket metoduyla elde edilmiştir. Araştırma bulgularına göre çiftçilerin \%25.91'inin kendi tecrübelerine göre pestisit tercihi yaptıkları belirlenmiştir. Çiftçilerin \%40'ının pestisit kalıntısının yıkanma ile yok olacağını düşündüklerini ve \%56'sının tarım ilacı uygulamasından sonra pestisit ambalajlarını gelişi güzel çevreye attıklarını tespit etmişlerdir.

Aydın, (2015), yaptığı çalışmada Konya ili Çumra, Ereğli ve Altınekin ilçelerinde fasulye üretiminde, çiftçilerin bitki koruma uygulamalarına yaklaşımlarına araştırmıştır. Bu amaçla 2014 yılında her ilçede fasulye yetiştiriciliği yapan 20 çiftçi ile anket çalışması sonuçlarından yararlanılmıştır. Ele alınan verilere göre az sayıda çiftçi bitki koruma alanındaki önerileri ilgili teknik personellerden alırken, çiftçilerin büyük çoğunluğunun tavsiye edilen doz miktarından fazla ilaç uyguladıkları, ilaçların ve gübrelerin boş artıklarını 
imha etmedikleri, ilaçlama ile hasat arasındaki süreye dikkat etmediklerini ve tarım ilacı uygulamaları sırasında koruyucu önlem almadıkları ortaya çıkmıştır

Önen vd., (2015), Adıyaman'ın Çelikhan ilçesinde yapmış oldukları çalışmada, ziraat odasına kayıtlı 900 aktif çiftçi içerisinden, basit rasgele örnekleme metodu ile 385 kişi ile görüşülmesi gerektiği belirlenmiştir. Eryılmaz ve ark. (2018), Samsun ilinde yapmış oldukları çalışmada anket yapılacak kişi sayısını belirlemek için, ana kitle oranlarına dayalı kümelendirilmiş tek aşamalı kolay tesadüfi örnekleme metodu kullanılarak 384 kişiyle görüşülmesi gerektiğini vurgulamışlardır.

Yukarıdaki çalışmalardan başka, üreticilerin tarım ilaçları kullanımı ile ilgili üretici tutumları davranışları ve çevresel duyarlılıkları ile ilgili anket çalışmaları; Antalya'da turunçgil yetiştiricileri ile (Özkan vd., 2003), Isparta'da elma yetiştiricileri ile (Demircan ve Yılmaz, 2005), Bingöl-Adaklı ilçesinde elma yetiştiricileri ile (Çelik ve Karakaya, 2017), Antalya (Akar ve Tiryaki, 2018) ve Bursa'da üreticiler ile (Kumral vd., 2018) yapılmıştır. Ayrıca Özyörük vd., (2019) Manisa-Salihli ve Sarıgöl ilçelerinde zirai ilaç bayilerinin bitki koruma ile ilgili mesleki tutum ve davranışlarının belirlenmesi konusunda anket çalışması yapmışlardır.

Yurtdışında da pestisit kullanıcılarının bilinç düzeyi ile ilgili yapılan çalışmalar vardır. Oluwole ve Cheke, (2009), Nijerya'daki Ekiti Eyaleti'nde çiftçiler ile yapmış oldukları çalışmada 150 kişi ile görüşme sağlamışlar ve görüşme yapılan kişilerin sadece \%26'sının okuma yazma bildiğini, okuma yazma bilenlerin sadece \%27.3'ünün tarım ilaçları üzerindeki etiket bilgilerini okuduğunu belirtmişlerdir. Sankoh vd., (2016), pestisitler üzerine yapmış oldukları çalışmada katılımcıların \%86.4'ünün en az bir tür pestisit kullandığını ve bu pestisitlerin kullanım alanının pirinç üretimi için olduğunu belirtmişlerdir. Çiftçilerin \% $\% 1{ }^{\prime} i$ ise pestisitlerin güvenli kullanımı ile ilgili hiçbir eğitim almadıklarını belirtmişlerdir. Jallow vd., (2017) ise, Kuveyt'de yapmış oldukları çalışmada, üreticilerinin tarım ilaçlarının güvenilir uygulaması hakkında bilgileri ve davranışları araştırılmıştır. 250 çiftçinin \%71'i tarım ilaçlarının sağlığa zararı olduğunu, \%65'i çevreye zarar verdiğini, \%70'i tarım ilaçlarının etiketindeki yazıları okumadığını, \%58'inin ilaçlama yaparken koruyucu araç ve malzeme kullanmadıklarını ifade etmişlerdir.

Çalışmamızda Manisa İlinde çiftçilerin tarım ilacı kullanımı ve seçimi konusundaki düşüncelerinin, deneyimlerinin, eğitim ve bilgi düzeyleri ile çevresel duyarlılıkların belirlenmesi amaçlanmıştır. Çiftçilerin pestisitlerin güvenli kullanımı konusundaki bilgi, tutum ve davranışlarını ve saklama koşullarını ortaya koyarak; pestisitlerle ilgili sorunların anlaşılmasına yardımcı olabilmek, bu alanda gerekli eğitim programlarının düzenlenmesine ve koruyucu önlemlerin alınmasına katkıda bulunabilmek hedeflenmiştir.

\section{Materyal ve Yöntem}

Araştırmada, anket yapılacak üreticiler, 2018-2019 yılında Manisa İlindeki birim alandan en fazla pestisit tüketen 17 ilçede tarım ürünü yetiştiren üreticilerden seçilmiştir. Üreticilerin, tarım ilacı kullanımı ve tarımsal ürünlerin kalıntı konusundaki anket sorularına verdikleri cevaplar çalışmanın ana materyalini oluşturmuştur. İkincil materyal olarak ise çeşitli kitaplar, makaleler, literatür ve raporlardan yararlanılmıştır. Anket formundaki soruların hazırlanmasında Manisa İl Tarım ve Orman Müdürlüğü verilerinden ve Akar ve Tiryaki, (2018), Akbaba, (2010), Kalıpçı vd., (2011) ve Demircan ve Yılmaz, (2005) çalışmalarından faydalanılmıştır. Bunların dışında konu ile ilgili çeşitli kuruluş ve araştırıcılar tarafından yapılan benzer araştırmalardan ve istatistiklerden de yararlanılmıştır. Ankette; çiftçilerin, arazi varlıkları, sosyo-ekonomik durumları, uyguladıkları tarım ilaçlarının kullanım amaçları, hangi dönemde uyguladıkları, uygulama metotları, tarım ilacı tercihine etki eden faktörler, tarım ilaçlarının elde edilme yolları ve tarım ilaçlarının gıdaların güvenirliliğine ve çevresel risklerine etkilerini kapsayan toplam 78 soru sorulmuştur. Üreticilerle yüz yüze görüşme şeklinde yapılan anket çalışmasından resimler Şekil 1'de verilmiştir. Çiftçilere pestisit kullanımı bilinç seviyesini ölçmek için yöneltilen sorulara verdikleri cevaplara üçlü Likert ölçeği ile puan verilmiştir (Likert, 1932). 


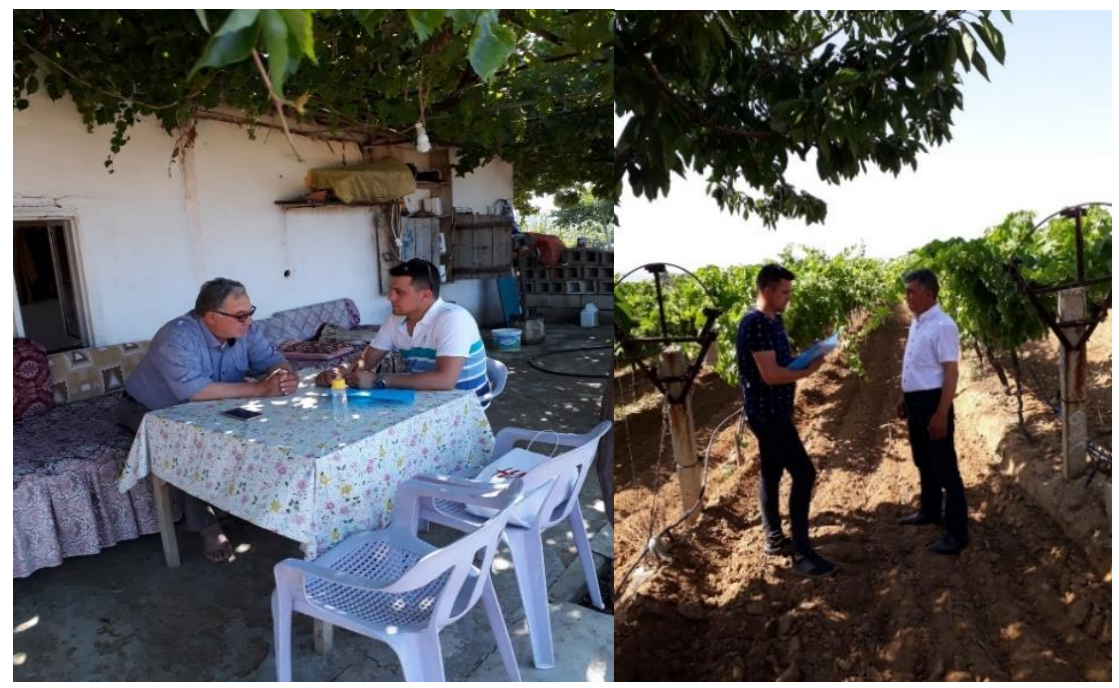

Şekil 1. Üreticilerle yapılan anket çalışmasından görüntüler

\section{1. Örnek Hacminin Belirlenmesi}

$\mathrm{Bu}$ tür çalışmalarda örnek hacmi, diğer bir ifade ile anket yapılacak çiftçi sayısı, o bölgeyi temsil edebilmelidir. Bunun için de verilerin doğasıyla uyumlu istatistiksel yöntemler kullanılmalıdır (Akar ve Tiryaki, 2018; Cankurt vd., 2010). Neyman yönteminde tabakanın alt ve üst sınırları ile ilgili arazi büyüklüğü gibi, çiftçilere ait özel bilgilere ihtiyaç vardır. Bu özel bilgiler de temin edilememiştir. Manisa ilinde 547737 kişi popülasyonu oluşturmaktadır. Bu popülasyonu temsil edecek örnek hacminin hesaplanmasında oransal yaklaşımdan yararlanılmış, ana kitle oranlarına dayalı kümelendirilmemiş tek aşamalı basit rastgele örnekleme metodu kullanılmıştır. Bu yaklaşımlar ile çalışmamızda örnek genişliğinin hesaplanmasında "Oran Ortalamalarına Dayalı Basit Rastgele Örnekleme Formülü" (Eşitlik 2.1) kullanılmıştır (Collins, 1986; Miran, 2003; Miran, 2009; Kılıç vd., 2018; Akar ve Tiryaki, 2018). Anket uygulanacak üretici sayısı, 0.05 hata payı (sapma) ve \%95 güven aralığı ile 384 olmuştur. P değeri bilinmez ise örnekleme sayısının yüksek çıkabilmesi için 0.5 kabul gören bir değerdir (Collins, 1986; Niyaz ve İnan, 2016; Eryllmaz vd., 2018). Nitekim Kiraz vd., (2012), Ery1lmaz vd., (2018) ve Akar ve Tiryaki, (2018)) çalışmalarında aynı yöntemle anket yapılacak üretici sayısı 384 bulunmuştur.

$n=\frac{(\mathrm{Z} \alpha / 2)^{2} \times \mathrm{p} \times(1-\mathrm{p})}{d^{2}}$

$\mathrm{n}=$ Örnek hacmi

$Z_{\alpha / 2}=$ istenen güven derecesine karş1lık gelen tablo değerini $\left(Z_{\alpha / 2}\right), \% 95$ güven aralığ için 1.960

$\mathrm{p}=$ üzerinde çalıştığımız özelliğin popülasyondaki oranı (ana kitle oranı) $(\mathrm{p}=0.5)$

$\mathrm{d}=$ Ortalamadan sapma, izin verilen hata payı $(0.05)$

$n=\frac{(1.960)^{2} \times 0.5 \times(1-0.5)}{0.05^{2}}=384.16$

İlçelerde anket uygulanacak çiftçi sayısı, o ilçenin köylerinin toplam nüfusa göre oransal dağılımı ile hesaplanmıştır. Benzer yöntemle köylerde anket yapılacak çiftçi sayısı da hesaplanmıştır. Manisa İli’nde anket yapılan çiftçi sayısının ilçelere göre sayı ve yüzde olarak dağılımı Tablo 1'de verilmiştir. 
Tablo 1

Manisa ilinde anket uygulanan çiftçi sayının ilçelere göre dağılımı

\begin{tabular}{lccc}
\hline İlçe & $\begin{array}{c}\text { İçedeki Köy Nüfusu } \\
\text { Toplamı* }\end{array}$ & Nüfus Oranı \% & $\begin{array}{c}\text { Anket Sayılarının İlçeye } \\
\text { Göre Dağılımı }\end{array}$ \\
\hline Ahmetli & 6.012 & $1.10^{* *}$ & $4^{* * *}$ \\
Akhisar & 48.329 & 8.80 & 34 \\
Alaşehir & 58.351 & 10.65 & 41 \\
Demirci & 22.308 & 4.07 & 16 \\
Gölmarmara & 5.606 & 1.02 & 4 \\
Gördes & 17.419 & 3.18 & 12 \\
Kırkağaç & 17.771 & 3.24 & 12 \\
Köprübaşı & 8.026 & 1.47 & 6 \\
Kula & 22.218 & 4.06 & 16 \\
Salihli & 55.474 & 10.13 & 39 \\
Sarıöl & 21.788 & 3.98 & 15 \\
Saruhanl & 24.961 & 4.56 & 11 \\
Selendi & 15.231 & 2.78 & 10 \\
Soma & 15.115 & 2.76 & 26 \\
Şehzadeler & 36.705 & 6.70 & 16 \\
Turgutlu & 22.416 & 4.09 & 105 \\
Yunusemre & 150.007 & 27.39 & $384^{* * * *}$ \\
\hline Toplam & 547.737 & 99.98 & \\
\hline
\end{tabular}

* 2018 yılında nüfus verileri (TÜİK, 2018)

$* *(6012 \times 100) / 547737=1.10$

$* * *(6012 \times 384) / 547737=4.21 ; 4$

**** Toplam gerçekleşen anket sayıs1 $=384$

\subsubsection{Verilerin Toplanması ve Analiz Edilmesi}

Yapılan anketlerden elde edilen veriler Likert Ölçeği, Khi-Kare Bağımsızlık Testi ile analiz edilmiştir ve istatistiksel olarak değerlendirilmiştir. Veriler oransal olarak da hesaplanarak tablo ve grafikler ile değerlendirilmiştir. Tarım ilacı kullanım bilinç düzeyinin hesaplanması anket sorularının cevaplarına verilen puanlar ile yapılmışıı. Çiftçilerin anket sorularına verdikleri olumlu cevaplardan başlayarak puanlama yapılmıştır. Alınan cevaplar 3'lü Likert Skalası ile (Likert, 1932) gruplandırılmıştır. Bu puanlama doğrultusunda çiftçilerin alacakları en fazla puan 48 olmuştur. Buna göre pestisit kullanımı bilinç düzeylerini belirleyen puan aralıkları şöyledir (Akar ve Tiryaki, 2018);

Max. Puan : 48

Aralik : 0-48

Yüksek seviyede bilinç düzeyi: 34-48 puan

Orta seviyede bilinç düzeyi: 25-33 puan

Düşük seviyede bilinç düzeyi: 0-24 puan

Çiftçilerin tarım ilacı kullanımı bilinç düzeyleri ile diğer parametreler arasında ilişkinin varlığı Khi-Kare $\left(x^{2}\right)$ Bağımsızlık Testi (Eşitlik 2.2) ile hesaplanmış, P değerleri de bulunmuştur (Hovardaoğlu, 1994; Düzgüneş vd., 1983). Khi-Kare değerlendirmesinde hipotez olarak karşılaştırılan parametreler arasında ilişki yoktur $\mathrm{H}_{\mathrm{o}}$ hipotezi kurulmuştur.

$x^{2}=\sum \frac{(G i-B \dot{\mathrm{I}})^{2}}{B i}$

$x^{2}:$ Sinıf sayısını 
$\mathrm{G}_{\mathrm{i}: \mathrm{i}}$ i. sınıfının gözlemlenen değeri

$\mathrm{B}_{\mathrm{i}:}$ i. sınıfının beklenilen değeri

Aralarında ilişkisi araştırılan parametreler şöyledir;

Tarım ilacı kullanımı bilinç seviyesi ile eğitim ilişkisi;

Tarım ilacı kullanımı bilinç seviyesi ile yaş ilişkisi

Tarım ilacı kullanımı bilinç seviyesi ile çiftçilik deneyimi ilişkisi

Tarım ilacı kullanımı bilinç seviyesi ile arazi varlığı ilişkisi

Bağımlı bulunan değişkenlerin arasındaki ilişkinin ne derece anlamlı ya da önemli olduğu da Kontingenz (Coefficient of Contingency, CC) yani bağımlılık katsayısı Eşitlik 2.3'e göre hesaplanarak değerlendirilmiştir (Düzgüneş, 1983).

$\mathrm{CC}=\sqrt{\frac{x^{2}}{N+x^{2}}}$

CC: Bağımlılık katsayısı

$x^{2}:$ Khi-Kare

$\mathrm{N}$ : Toplam anket yapılan çiftçi sayısı

\section{Bulgular ve Tartışma}

Çalışmada üreticilerin demografik durumları oransal olarak hesaplanarak, tablo ve grafikler ile değerlendirilmiştir. Çalışmaya katılan üreticilerin \%31.2'si 21-30 yıl çiftçilik tecrübesi olduğunu, \%53.1 ilkokul mezunu olduğunu, \%42.4'ü 1-20 da araziye sahip olduğunu ve \%30.2'si 45-54 yaş aralığında olduğunu belirtmişlerdir. Üreticilerin çiftçilik deneyimleri ve arazi varlıkları ilgili verilerin en küçük, en büyük ve ortalama değerleri hesaplanmıştır (Tablo 2).

Tablo 2

Çiftçilerin genel özeliklerine ait tanımlayıcı istatistikler

\begin{tabular}{lcccc}
\hline İfade & En küçük & En büyük & Ortalama & Standart sapma \\
\hline Çiftçilik deneyimi (yıl) & 5 & 45 & 23 & 11 \\
Arazi varlığı (da) & 5 & 100 & 27 & 21 \\
\hline
\end{tabular}

Üreticilerin pestisitlerin çevreye etkileri konusundaki görüşleri Tablo 3'de verilmiştir. Üreticilerin; \% 73.7'si pestisitlerin kuşlara zararlı olabileceğini, \%71.9'u akarsu ve göllerde kirlilik yapabileceğini, \%70.8'i memelilere zararlı olabileceğini, \%70.1'i sürüngenlere zararlı olabileceğini ve \%67.2'si yararlı böceklere ve arılara zararlı olabileceğini belirtirmişlerdir. 
Tablo 3

Pestisitlerin çevreye etkileri konusunda çiftçi görüşleri

\begin{tabular}{|c|c|c|c|c|c|c|}
\hline \multirow[t]{2}{*}{ İfade } & \multicolumn{2}{|c|}{$\begin{array}{l}\text { Kesinlikle } \\
\text { katılıyorum }\end{array}$} & \multicolumn{2}{|c|}{$\begin{array}{l}\text { Kararsızım. } \\
\text { görüşüm yok }\end{array}$} & \multicolumn{2}{|c|}{$\begin{array}{l}\text { Kesinlikle } \\
\text { katılmıyoru } \\
\text { m }\end{array}$} \\
\hline & Say1 & $\%$ & Say1 & $\%$ & Say1 & $\%$ \\
\hline Kuşlarda zarar oluşturur & 283 & 73.7 & 61 & 15.9 & 40 & 10.4 \\
\hline Gö1/akarsularda kirlilik olur & 276 & 71.9 & 64 & 16.7 & 44 & 11.4 \\
\hline Memelilerde zarar oluşturur & 272 & 70.8 & 67 & 17.5 & 45 & 11.7 \\
\hline Sürüngenlerde zarar oluşturur & 269 & 70.1 & 67 & 17.4 & 48 & 12.5 \\
\hline Yararlı böceklerde ve arılarda zarar oluşturur & 258 & 67.2 & 80 & 20.8 & 46 & 12.0 \\
\hline
\end{tabular}

Üreticilerin, pestisitlerin insan sağlığına etkileri hakkındaki görüşleri de irdelenmiştir (Tablo 4). Çiftçilerin, $\% 69$ 'u pestisitlerin kısa süreli zehirlenme yapabileceğini, \%68.5'i kanserojen etkisinin olabileceğini, \%66.9'u deri üzerini tahriş edebileceğini ve \%62'si de bilmediğimiz bazı hastalıklara sebep olabileceğini belirtmişlerdir.

Akar ve Tiryaki, (2018)'nin çalışmalarında ise üreticilerin \%40'ı tarım ilaçlarının çevreye herhangi bir zararl1 etkisinin olmayacağını, \%66'sı ürünlerinde olası tarım ilacı kalıntılarının kanser oluşturmayacağını, \%33.3'ü zararını bildiklerini fakat kullanmak zorunda olduklarını belirtmişlerdir. Kumral vd., (2018) üreticilerin pestisitlerin çevreye ve insana olan olumsuz etkileri bilme oranının $\% 53$ olduğunu bildirmişlerdir. Çiftçilerin uygulama sonrası artan ilaçlı suyu ne yaptıkları da araştırılmıştır (Tablo 5). Üreticilerin \%74.2'si artan ilaçlı suyu tarlanın kenarına boşaltmakta, \%21.1'i boş bir araziye püskürtmekte, \%2.4'ü kanalizasyona dökmekte \%1.8'i sulama kanalına ve akarsuya boşaltmakta, \%0.5'i diğer yerlere boşaltmaktadır.

Tablo 4

Üreticilerin insan sağlığına pestisitlerin etkileri konusunda görüşleri

\begin{tabular}{|c|c|c|c|c|c|c|}
\hline \multirow[t]{2}{*}{ İfade } & \multicolumn{2}{|c|}{$\begin{array}{c}\text { Kesinlikle } \\
\text { katıliyorum }\end{array}$} & \multicolumn{2}{|c|}{$\begin{array}{c}\text { Kesinlikle } \\
\text { katılmiyorum }\end{array}$} & \multicolumn{2}{|c|}{$\begin{array}{l}\text { Kararsızım } \\
\text { görüşüm yok }\end{array}$} \\
\hline & Say1 & $\%$ & Say1 & $\%$ & Say1 & $\%$ \\
\hline Kisa süren zehirlenme yapar & 265 & 69.0 & 42 & 10.9 & 77 & 20.1 \\
\hline Kanserojen etkisi olur & 263 & 68.5 & 47 & 12.2 & 74 & 19.3 \\
\hline Deri üzerini tahriş eder & 257 & 66.9 & 43 & 11.2 & 84 & 21.9 \\
\hline Bilmediğimiz bazı hastalıklara sebep olur & 238 & 62.0 & 31 & 8.1 & 115 & 29.9 \\
\hline
\end{tabular}

Tablo 5

Çiftçilerin artan ilaçlı su ile ilgili davranışları

\begin{tabular}{lrc}
\hline İfade & Sayı & $\%$ \\
\hline Bahçede bir kenara dökme & 285 & 74.2 \\
Boş bir araziye püskürtme & 81 & 21.1 \\
Kanalizasyona dökme & 9 & 2.4 \\
Sulama kanalı/akarsuya boşaltma & 7 & 1.8 \\
Diğer & 2 & 0.5 \\
\hline Toplam & 384 & 100.0 \\
\hline
\end{tabular}

Boş ilaç kaplarının akıbeti konusunda, katılımcıların \%68.5'i kapları yaktığını, \%19'u poşetleyerek çöp kutusuna attığını, \%6.3'ü çevreye attığını, \%4.9'u tekrar kullandığını, \%1.3’ü de toprağa gömdügünü belirtmişlerdir (Tablo 6). Akar ve Tiryaki, (2018), üreticilerin \%55'inin boşalan ilaç kutularını yakarak imha ettiklerini, Akbaba, (2010) çiftçilerin \%61.1'inin depolayıp daha sonra yaktıklarını, Tuna vd., (2012) 
üreticilerin \%32.9'u yakarak ya da gömerek imha ettiklerini, Çelik ve Karakaya, (2017) da üreticilerin $\% 50$ 'sinin bir yerde depolayarak daha sonra yaktıklarını belirtirmişlerdir.

Tablo 6

Boş ilaç kutularını/ambalajlarını imha etme yöntemleri

\begin{tabular}{lcc}
\hline Davranış & Sayı & $\%$ \\
\hline Yakarak imha etme & 263 & 68.5 \\
Çöpe atma & 73 & 19.0 \\
Çevreye atma & 24 & 6.3 \\
Tekrar kullanma & 19 & 4.9 \\
Toprağa gömme & 5 & 1.3 \\
Toplam & 384 & 100.0 \\
\hline
\end{tabular}

Çiftçilerin pestisit kalıntısı hakkındaki görüşleri de ele alınmıştır (Tablo 7). Çiftçilerin \%40.1'i bazı pestisitlerin kalıntı bırakabileceğini, \%26.6's1 pestisit kalıntılarının yıkanma ile kaybolacağını, \%21.6's1 kalıntı bırakmayacağını, \%11.7'si pestisit kalıntısı hakkında bilgisinin olmadığını belirtmişlerdir. Özkan vd., (2003) çalışmalarında çiftçilerin \%70.4' ü ürünlerde tarım ilacı kalıntısı olabileceğini belirtmişlerdir. Akar ve Tiryaki, (2018) ise çalışmalarında çiftçilerin \%23.3'ü kalıntılarının yıkanma ile giderileceğini, \%24.9'u kalıntı kalmayacağını, \%34.1'i bazı ilaçların kalıntısı olabileceğini, \%17.7'si kalıntı konusunda bilgilerinin olmadığını açıklamışlardır.

Tablo 7

Üreticilerin pestisit kalıntıları konusunda görüşleri

\begin{tabular}{lcc}
\hline İfade & Sayı & $\%$ \\
\hline Bazı tarım ilaçlarının kalıntısı olabilir & 154 & 40.1 \\
Kalıntı yıkama ile yok olur & 102 & 26.6 \\
Kalıntı bırakmaz & 83 & 21.6 \\
Pestisit kalıntıları konusunda bir düşüncem yok & 45 & 11.7 \\
Toplam & 384 & 100.0 \\
\hline
\end{tabular}

Ayrıca üreticilerin zararlı organizmalara karşı, \%97.9'u kimyasal mücadeleyi \%2.1'i de biyolojik mücadeleyi uyguladıklarını belirtmişlerdir. Çiftçilerin \%44.6'sı su ile hastalık bulaşması veya yabancı ot gözlemlediğini belirtirken, \%33.3'ü gözlemlemediğini belirtmişlerdir. Çiftçilerin uygulamada ilaç dozunu belirlemede \%63.8'i tarım ilaç bayilerinin önerilerine, \%19.0'1 tarım ilacı ambalajı bilgilerine, \%9.4'ü tarım il ve ilçe müdürlüğü yetkililerin tavsiyelerine göre, \%5.7'si kendi bilgi ve tecrübelerine, \%1.3'ü komşu ve akrabaların önerilerine ve \%0.8'i internet, radyo ve televizyon programlarına göre karar verdiklerini belirtmişlerdir. Üreticilerin \%44.0'ü ilaçlama zamanını belirlemede ilaç bayilerinden yararlandıklarını ve \%54.4'ü ilaç seçiminde zirai ilaç bayilerinin tavsiyelerine uyduğunu belirtmiştir. İlaç uygulama zamanını belirlemede Akar ve Tiryaki (2018)'nin çalışmalarında üreticilerin \%42.1'i, Tanrıvermiş, (2000), çalışmasında ise \%40.2'si tarım ilacı bayilerinden yararlanmıştır. Benzer olarak Kalıpçı vd., (2011)'nın belirttiklerine göre çiftçilerin \%33.3'ü ilaç dozunu belirlemede zirai ilaç bayilerinin tavsiyelerine uymaktadırlar. Akar ve Tiryaki, (2018) çiftçilerin \%83.3'ünün hastalık zararlı ve yabancı otlarla kimyasal mücadele yaptığını, \%46.8'inin su ile hastalık bulaşması veya yabancı ot gözlemlemediğini, \%42.1'inin ilaçlama zamanını belirlemede tarım ilacı bayilerinden yararlandığını \%71.4'ünün ilaç dozunu ayarlamada ilaç bayilerin önerilerine uyduğunu belirtmişlerdir.

Üreticilerin \%64,3 ü hastalık, zararlı ve yabancı ot görülmediği zaman ilaçlama yapmadığını belirtmiştir. Akar ve Tiryaki, (2018)'in çalışmasında bu oran \%54.5, Kumral vd., (2018)'nın çalışmalarında \%66'dır. Özkan vd., (2003)'e göre çiftçilerin \%74.15'i ilaçlamayı herhangi bir zararlı organizma görüldüğünde yapmaktadır. Tanrıvermiş, (2000) ise üreticilerin \%78.75'inin herhangi bir zararlı organizma görülmeden ilaçlama yaptıklarını belirtmiştir. Çiftçilerin ilacı alırken ruhsatlı olmasına dikkat etme oranları, çalışmamızda, Akbaba, (2010) ve Akar ve Tiryaki, (2018)'nin araştırmalarında, sırasıyla, \%81.3, \%81.5 ve 
\%71.2 olarak bulunmuştur. Son kullanma tarihlerine üreticilerin dikkat etme oranı çalışmamızda \%83.9, Tanrıvermiş, (2000)'in çalışmasında \%93.75 ve Akar ve Tiryaki, (2018)'nin çalışmasında \%79.1, olarak bulunmuştur. Bu çalışmada çiftçilerin pestisit seçiminde yararlandıkları kaynaklar da araştırılmış, üreticilerin \%54.4'ü ilaç seçiminde zirai ilaç bayilerinin önerilerine uymuştur. Bu değerler ve Özkan vd., (2003), Kalıpç1 vd., (2011) ve Akar ve Tiryaki (2018) tarafindan sırasıyla, \%42.78, \%35.8 ve \%66.9 olarak bulunmuştur.

Ankete katılan çiftçilerin \%71.4'i tarım ilacını zirai ilaç bayilerinden temin ettiğini belirtmişlerdir. Bu oran Tanrıvermiş, (2000), Akbaba, (2010), Cevizci vd., (2012) ve Akar ve Tiryaki, (2018) çalışmalarında, sırasıyla, \%81.25, \%89.90, \%47.90 ve \%92.10 olarak bulunmuştur. Çiftçilerin ilaç seçiminde ilacın etkili olmasına dikkat etme oranı, bu çalışmamızda ve Akar ve Tiryaki (2018)'nin çalışmasında, sırasıyla \%85.7 ve \%77.8'dir. Çiftçilerin tarım ilaçlarının etkisizlik sebebini, \%50.8'i etken madde yetersizliğine, \%15.3'ü doz ayarlaması yapamamaya, \%16.5'i bitkinin dayanıklılık gösterdiğine bağlamışlardır.

Çiftçilerin pestisit uygulamaya karar verirken, \%82.8'ü bitki koruma probleminin yaygınlık durumuna, \%17.2'si pestisitin fiyatına ve ilaçlamanın maliyetine bakmaktadır. Kalıpçı vd., (2011) ve Akar ve Tiryaki, (2018)'nin çalışmalarında bu oranlar, sırasıyla, \%64.1, \%32.5, ve \%89.4, \%10.6 olarak bulunmuştur.

Üreticilerin \%59.9'u tarım ilaçlarını depolarında, \%25.5'i özel bir dolapta, \%5.7'si ahır ve hayvan barınağında, \%4,4'ü özel bir odada rafta, \%2.9'u tarım ilacını evin herhangi bir yerinde depoladıklarını belirtmişlerdir. Çelik ve Karakaya, (2017) ile Akar ve Tiryaki (2018)'nin çalışmalarında bu oranlar, sırasıyla, $\% 35, \% 50, \% 15 \% 57.7$ ve $\% 22, \% 5, \% 4, \% 1.3$ olarak bulunmuştur.

Çiftçilerin \%15.4'ü PHI'ne (son ilaçlama ile hasat arasında olması gereken süre) dikkat etmediğini belirtmiştir. Çiftçilerin, \%59.1'i ise maksimum kalıntı limiti (MRL) kavramını duymadıklarını belirtmiştir. Akar ve Tiryaki (2018) çalışmalarında çiftçilerin \%12.7'si PHI değerine dikkat etmediğini, \%65.6's1 MRL kavramını duymadıklarını belirtmişıerdir.

Çiftçilerin tarım ilacı kullanımı bilinç seviyesi üçlü Likert Ölçeği ile alınan cevaplara puan verilerek hesaplanmıştır. Üreticilerin \%63.8'i yüksek, \%25.3'ü orta, \%10.9 u da düşük bilinç düzeyine sahiptir (Tablo 8). Kızılaslan ve Kızılaslan, (2005) ve Akar ve Tiryaki, (2018)'nin çalışmalarında bu oranlar, sırasıyla, $\% 23.53, \% 49.02, \% 27.45$ ve $\% 58.2, \% 28.3, \% 13.5$ şeklinde bulunmuştur.

Manisa İlinde üreticilik yapan çiftçilerin pestisit kullanım bilinç düzeyi ile aldıkları eğitim süreleri, çiftçilerin yaşları, çiftçilik deneyimi süreleri ve arazi varlıkları arasında bir ilişkinin olup olmadığı da araştırılmıştır. Üreticilerin eğitim durumlarına göre pestisit kullanımı bilinç düzeyi Tablo 8'de verilmiştir. Uygulanan KhiKare testine göre bu 2 parametre arasındaki ilişki önemli bulunmuştur. Bağımlılık katsayısı da Eşitlik 2.3'e göre 0.29 olarak hesaplanmıştır. Eğitim seviyesi arttıkça üreticilerin pestisit kullanım bilinç düzeyleri de artmaktadır. En yüksek bilinç seviyesi de (\%84.0) üniversite mezunlarında çıkmıştır.

Tablo 8

Çiftçilerin eğitim durumlarına göre pestisit kullanım bilinç düzeyleri

\begin{tabular}{|c|c|c|c|c|c|c|c|c|c|}
\hline \multicolumn{10}{|c|}{ Pestisit Kullanım Bilinç Seviyesi } \\
\hline \multirow[b]{2}{*}{ Eğitim } & \multicolumn{2}{|c|}{ Yüksek } & \multicolumn{2}{|c|}{ Orta } & \multicolumn{2}{|c|}{ Düşük } & \multicolumn{3}{|c|}{ Toplam } \\
\hline & Sayı & $\%$ & Sayı & $\%$ & Say 1 & $\%$ & Sayı & $\%$ & $\begin{array}{l}\text { Tüm anket } \\
\text { bazında } \%\end{array}$ \\
\hline Okur, yazar değil & 6 & 22.2 & 9 & 33.3 & 12 & 44.5 & 27 & 100 & 7.1 \\
\hline Okuryazar & 14 & 46.7 & 11 & 36.7 & 5 & 16.6 & 30 & 100 & 7.8 \\
\hline İlkokul & 132 & 64.7 & 53 & 26.0 & 19 & 9.3 & 204 & 100 & 53.1 \\
\hline Ortaokul & 35 & 77.8 & 8 & 17.8 & 2 & 4.4 & 45 & 100 & 11.7 \\
\hline Lise ve dengi okul & 35 & 70.0 & 12 & 24.0 & 3 & 6.0 & 50 & 100 & 13.0 \\
\hline Üniversite & 21 & 84.0 & 3 & 12.0 & 1 & 4.0 & 25 & 100 & 6.5 \\
\hline Lisansüstü & 2 & 66.7 & 1 & 33.3 & 0 & 0.0 & 3 & 100 & 0.8 \\
\hline Genel Toplam & 245 & 63.8 & 97 & 25.3 & 42 & 10.9 & 384 & 100 & 100.0 \\
\hline
\end{tabular}

Çiftçilik deneyim süresi ve bilinç düzeyleri ile ilgili veriler Tablo 9'da verilmiştir. Khi-Kare testine göre üreticilerin çiftçilik deneyim yılları ile pestisit bilinç düzeyleri arasında bir ilişki yoktur. Ancak 31-40 yıl aralığında (orta seviyede tecrübeye sahip) ise en yüksek bilinç düzeyi (\%78.8) bulunmuştur. Akar ve Tiryaki, 
(2018) ise çiftçilik deneyimi süresi ile tarım ilacı kullanımı bilinç seviyesi arasındaki ilişki önemli bulunmuştur.

Tablo 9

Çiftçilik deneyimi sürelerine göre pestisit kullanım bilinç düzeyleri

\begin{tabular}{|c|c|c|c|c|c|c|c|c|c|}
\hline \multirow{3}{*}{$\begin{array}{l}\text { Çiftçilik } \\
\text { Deneyimi (y1) }\end{array}$} & \multicolumn{6}{|c|}{ Pestisit Kullanım Bilinç Seviyesi } & \multirow{2}{*}{\multicolumn{3}{|c|}{ Toplam }} \\
\hline & \multicolumn{2}{|c|}{ Yüksek } & \multicolumn{2}{|c|}{ Orta } & \multicolumn{2}{|c|}{ Düşük } & & & \\
\hline & Say1 & $\%$ & Say1 & $\%$ & Say 1 & $\%$ & Say1 & $\%$ & $\begin{array}{l}\text { Tüm anket } \\
\text { bazında } \%\end{array}$ \\
\hline $1-10$ & 32 & 59.3 & 17 & 31.5 & 5 & 9.3 & 54 & 100 & 14.1 \\
\hline $11-20$ & 47 & 57.3 & 24 & 29.3 & 11 & 13.4 & 82 & 100 & 21.3 \\
\hline $21-30$ & 71 & 59.2 & 36 & 30.0 & 13 & 10.8 & 120 & 100 & 31.3 \\
\hline $31-40$ & 78 & 78.8 & 12 & 12.1 & 9 & 9.1 & 99 & 100 & 25.8 \\
\hline $41+$ & 17 & 58.6 & 8 & 27.6 & 4 & 13.8 & 29 & 100 & 7.5 \\
\hline Genel Toplam & 245 & 63.8 & 97 & 25.3 & 42 & 10.9 & 384 & 100 & 100.0 \\
\hline
\end{tabular}

Çalışmamızda ve Akar ve Tiryaki, (2018)'nin çalışmalarında çiftçilerin pestisit kullanım bilinç düzeyi ile yaş durumları ve arazi varlıkları arasında istatistiki olarak önemli bulunmamakla birlikte en yüksek bilinç düzeyi $(\% 69.8)$ orta yaş grubunda (45-54) bulunmuştur.

\section{Sonuçlar}

$\mathrm{Bu}$ anket çalışmasında üreticilerin yaş, çiftçilik deneyim süreleri ve arazi varlıklarının büyüklügü ile pestisit kullanımı bilinç düzeyi arasında bir bağlantı bulunamamıştır. Ancak üreticilerin tarım ilacı kullanımı bilinç düzeyi ile eğitim süreleri ile arasında ilişkinin önemli olduğu bulunmuştur. Çiftçilikte tecrübe sahibi ve iyi eğitim almış kişilerin bilinç düzeyleri yüksek çıkmıştır. Bu sonuçla çoğu disiplinde olduğu gibi eğitimin rolünün önemi bir kez daha ortaya çıkmıştır. Diğer verilerden de şu sonuç çıkartılabilir; birçok çiftçi tarım kuruluşları ve zirai ilaç bayilerine güvenerek tarımsal faaliyetlerini ve ilaçlamalarını yürütmektedirler. $\mathrm{Bu}$ nedenle Ziraat Odalarına ve Tarım ve Orman Bakanlığı teknik teşkilatlarına bu konuda önemli görevler düşmekte, üreticileri bilinçlendirmek ve eğitmek için yapılan çalışmaların amacına ulaşması için hassas davranmaları gerekmektedir.

\section{Teşekkür}

Çalışmanın yürütülmesi sürecinde yardımlarından dolayı Esra ERDİL'e teşekkür ederiz. Bu makale Mehmet ERDİL'in yüksek lisans tez çalışmasının bir bölümüdür.

\section{Yazar Katkıları}

Mehmet ERDILL: Veri toplamış, değerlendirmesini yapmış ve makaleyi yazmıştır.

Osman TIRYAKİ: Veri analizi ve istatistiksel değerlendirme yapmış, makaleyi düzenlemiştir.

\section{Çıkar Çatışması}

Yazarlar çıkar çatışması bildirmemişlerdir.

\section{Kaynaklar}

Altıkat, A., Turan, T., Torun, F.E. (2009). Türkiye'de pestisit kullanımı ve çevreye olan etkileri. Atatürk Üniv Ziraat Fak Derg.,40 (2):87-92.

Akar, Ö., Tiryaki, O. (2018). Antalya ili’nde üreticilerin pestisit kullanımı konusunda bilgi düzeyi ve duyarlılıklarının araştırılması. Süleyman Demirel Üniversitesi Ziraat Fakültesi Dergisi, 13 (1):60-70. 
Akbaba, B. Z. (2010). Adana İli turunçgil yetiştiriciliği ve insektisit kullanımının değerlendirilmesi. Çukurova Üniversitesi, Fen Bilimleri Enstitüsü, Yüksek Lisans Tezi, Adana, 80s.

Akpinar, T., Özyıldırım, K. (2016). Trakya Bölgesi'nde tarımsal faaliyette bulunan çiftçilerin iş sağlı̆̆ ve güvenliği açısından değerlendirilmesi. Çalışma ve Toplum 3: 1231-1270.

Aydın, S. (2015). Konya ili fasulye üreticilerinin bitki koruma uygulamalarına yaklaşımlarının belirlenmesi Yüksek Lisans Tezi, Selçuk Üniversitesi Fen Bilimleri Enst. Bitki Koruma Anabilim Dalı, Türkiye.

Cankurt, M., Miran, B., Şahin, A. (2010). Sığır eti tercihlerini etkileyen faktörlerin belirlenmesi üzerine bir araştırma izmir ili örneği. Hayvansal Üretim, 51(2): 16-22.

Cevizci, S., Bakar, C. (2012). Çanakkale Gelibolu'da tarım ilaçlarının kontrolsüz ve güvensiz kullanımı ss,220-222. 1. Tarım Sağlığ ve Güvenliği Sempozyumu, 6-7 Nisan 2012, Şanlıurfa

Collins, M. (1986). Sampling (Editör: R.Worcesterve ark. 1986). Consumer market research handbook.

Çelik, A., Karakaya E. (2017). Bingöl ili Adaklı ilçesi elma üreticilerinin tarımsal ilaç kullanımında bilgi tutum ve davranışlarının değerlendirilmesi ve ekonomik analizi. Türk Tarım Doğa Bilimleri Dergisi, 4 (2): 119-129.

Delen, N., Tosun, N., Toros, S., Öztürk, S., Yücel, A., Çalı, S. (1995). Tarım ilaçları kullanımı ve üretimi Türkiye Ziraat Mühendisliği IV. Teknik Kongresi, T.C. Ziraat Bankası Kültür Yayınları 26: 10151028.

Delen, N., Durmuşoğlu, E., Güncan, A., Güngör, N., Turgut, C., Burçak, A.(2005). Türkiye'de pestisit kullanımı kalıntı ve duyarlılık azalışı sorunları Türkiye Ziraat Mühendisliği 6 1ncı Teknik Kongresi, 3-7 Ocak 2005, 629-648.

Delen, N., Tiryaki, O., Türkseven, S., Temur, C. (2015). Türkiye'de pestisit kullanımı kalıntı ve dayanıklılık sorunları, çözüm önerileri ss, 758-778. Türkiye Ziraat Müh. VIII. Teknik Kongresi, 12-16 Ocak 2015, Türkiye.

Demircan, V., Yılmaz, H. (2005). Isparta ili elma üretiminde tarımsal ilaç kullanımının çevresel duyarlılık ve ekonomik açıdan analizi, Ekoloji 14 (57): 15-2.

Düzgüneş, O., Kesici, T., Gürbüz, F. (1983). İstatistik metodları. Ankara Üniversitesi Ziraat Fakültesi Yayınlar1, 861, Ders Kitabı:229. Türkiye, 218s.

Eryılmaz, G.A., Kılıç, O., Başer, U. (2018). Gıda güvenliği konusunda tüketici davranışlarının belirlenmesi Samsun ili kentsel alan örneği. Çanakkale Onsekiz Mart Üniversitesi Fen Bilimleri Enstitüsü Dergisi, 4(2): 237-245.

Hovardaoğlu, S. (1994). Davranış bilimleri için istatistik, Hatiboğlu Yayınları No: 79. Türkiye, 365s.

Jallow, M.F.A., Awadh, D.G., Albaho, M.S., Devi, V.Y, Thomas, B.M. (2017). Pesticide knowledge and safety practices among farm workers in kuwait: results of a survey. International Journal of Environmental Research and Public Health, 14,340. DOI:10.3390/ijerph14040340.

Kalıpçı, N., Özdemir, C., Öztaş, H. (2011). Çiftçilerin pestisit kullanımı ile ilgili eğitim ve bilgi düzeyi ile çevresel duyarlı1ıklarının araştırılması. Tübav Bilim Dergisi, 4 (3),179-187.

Kara, A., (1987). Zirai mücadelede erken uyarının önemi. Hasad Dergisi, 23, 24-25.

Kılıç, B., Uzundumlu, A.S., Tozlu, G. (2018). Fındık üretiminde kimyasal ilaç kullanımının çevresel duyarlılık yönünden incelenmesi. giresun ili örneği, Türk Tarım ve Doğa Bilimleri Derg. 5(4): 396-405.

Kiraz, E.D.E., Ergin, F., Serter, E., Karakaya, Ş. (2012). Tarım işgücünde pestisit etkilenimi aydın farkındalık çalışması, ss, 158-164. 1. Tarım Sağlığı ve Güvenliği Sempozyumu, 6-7 Nisan 2012, Şanlıurfa

Kumral, N.A., Balta, P., Özdemir, B. N., Uludağ, G. ve Şahin, S. (2018). Bursa ilinde çiftçilerin pestisitleri uygulama davranışları üzerine bir survey çalışma. Bursa Uludağ Üniversitesi Ziraat Fakültesi 10. Tomurcuk Şenliği, Tarım ve Gıda Öğrenci Kongresi, 7-8 Mayıs 2018, Bursa

Miran, B. (1996). Çok amaçlı karar alma yöntemiyle salihli ve ahmetli yöresinde tarımsal ilaçların optimum kullanımı üzerine bir araştırma E. Ü. Araştırma Fonu Saymanlığı Proje No: 93 ZRF 047, Türkiye.

Miran, B. (2003). Temel istatistik Ege Üniversitesi Basımevi, ISBN 975-9308800 Bornova, Türkiye.

Niyaz, Ö.C., İnan, H.İ. (2016). TR22 Güney Marmara Bölgesindeki tüketicilerin süt ve süt ürünleri tüketim düzeylerinin belirlenmesi. ÇOMÜ Zir. Fak. Derg., 2016: 4 (2): 7-13. 
Oluwole, O., Cheke, R.A. (2009). Health and environmental impacts of pesticide use practices a case study of farmers in ekiti state, nigeria. International Journal of Agricultural Sustainability 7(3): 153-163.

Önen, C., Avcı, S., Güneş, G. (2015). Çiftçilerin tarım ilaçlamasında kullandı̆̆ı koruyucu sağglk önlemleri. Turk J Public Health,13(2): 147-154.

Özkan, B., Akçagöz, H.V., Karadeniz, C.F. (2003). Antalya ilinde turunçgil üretiminde tarımsal ilaç kullanımına yönelik üretici tutum ve davranışları. Anadolu Dergisi, 13 (2): 103-116.

Özyörük, A., Erbek, E., Arslan, Ü. (2019). Manisa ili Salihli ve Sarıöl ilçelerindeki zirai ilaç bayilerinin mesleki tutum ve davranışları ve üreticiler ile ilgili gözlemleri. Kahramanmaraş Sütçü İmam Üniversitesi Tarım ve Doğa Dergisi, 22: 126-133.

Peker, E.A (2012). Konya ili domates üretiminde tarımsal ilaç kullanımına yönelik çevresel duyarlılık analizi. I ğdır Üniversitesi Fen Bilimleri Enstitüsü Dergisi, 2(1): 47-54.

Resmi Gazete, (2014). Bitki koruma ürünlerinin önerilmesi, uygulanmast ve kaylt işlemleri hakkında yönetmelik Gıda Tarım ve Hayvanc1lık Bak. 3 Aralık 2014, 29194.

Sankoh, A.I., Whittle, R., Semple, K.T., Kones, K.C., Sweetman ,A.J. (2016). An assessment of the 1mpacts of pesticide use on the environment and health. Environment International, 94: 458-466.

Sataloğlu, N., Aydın, B., Turla, A. (2007). Pesticide poisoning. TAF Prev Med Bull ; 6(3):169-174.

Tanrıvermiş, H. (2000). Orta Sakarya Havzası'nda domates üretiminde tarımsal ilaç kullanımının ekonomik analizi. Ankara Üniversitesi. Proje Raporu 2000-4.

Tarakcı, Ü., Türel, İ. (2009). Halk să̆lığı amaçlı kullanılan pestisitlerin (biyosidal) güvenilirlik standartlarının karşılaştırılması. Van Vet J. 20(1):11-18.

Tiryaki, O. (2016). Türkiye'de yapılan pestisit kalıntı analiz ve çalışmalar. Erciyes Üniversitesi Fen Bilimleri Enstitüsü Dergisi, 32(1):72-82.

Tiryaki, O., Canhilal, R., Horuz, S. (2010). Tarım ilaçları kullanımı ve riskleri. Erciyes Üniversitesi Fen Bilimleri Enstitüsü Dergisi, 26 (2):154-169.

Tosun, N., Karabay, N.Ü., Sayım, F. (2001). Pesticide usage and their potential adverse impacts on living organisms. Anadolu J AARI 11(1):113-125.

Tuna, R.Y., Gün, İ., Ceyhan, O. (2012). Çiftçilerin pestisitleri saklama koşulları ve güvenli kullanımı konusunda bilgi, tutum ve davranışları ss, 155-157. 1. Tarım Sağlığı ve Güvenliği Sempozyumu, 6-7 Nisan 2012, Şanlıurfa.

Turabi, M.S. (2004). Türkiye Cumhuriyeti'nde tarımsal ilaç, tesçil ve ruhsat sistemi Tarımsal İlaçlar ve Organik Tarım Konf., KTMMOB ZMO, 9 Haziran 2004, Türkiye.

TÜİK, (2019). Tarımsal ilaç kullanımı. http://www.tuik.gov.tr/PreTablo.do?alt_id=1001 Erişim tarihi, 10 Eylül 2019

WCED, (1987). World commission on environment and development, our common future the brundtland report Oxford University Press, Oxford.

Yücel, A., Çıkman, E., Yücel, M. (1995). Güneydoğu Anadolu Bölgesi (GAP) uygulamaya konulmadan önce Harran ovasında çiftçinin tarımsal mücadeleye bakısı. GAP Bölgesi Bitki Koruma Sorunları ve Çözüm Önerileri Sempozyumu, 27-29 Nisan 1995, Türkiye, s: 53-65. 